\title{
THE MARKET ORIENTATION AND PERFORMANCE RELATIONSHIP: THE EMPIRICAL LINK IN PRIVATE UNIVERSITIES
}

\author{
Sefnedi \\ Postgraduate Management Program, University of Bung Hatta, \\ Padang, West Sumatera, Indonesia. \\ Corresponding author; Email: sefnediphd@yahoo.com
}

\begin{abstract}
This study examines the empirical link between three dimensions of market orientation, namely, student orientation, competitor orientation and inter-functional coordination, and overall private university performance in Kopertis X. It was based on an empirical investigation of private universities located in Indonesia's provinces of West Sumatera, Riau, Jambi, and Kepulauan Riau. The primary data for the study were collected from a self-administered mail survey of 237 questionnaires from the private university resulting in a sample of 114 usable responses being returned. From the application of the multiple regression analysis it was concluded that all three dimensions of market orientation had a significant impact on private university performance. Student orientation as a predictor variable is the strongest predictor of private university performance and followed by competitor orientation, and inter-functional coordination.
\end{abstract}

Keywords: Market orientation, private university, performance.

\section{Introduction}

There has been a proliferation of research published over the past three decades on the relationship between market orientation and university performance (Algarni \& Thalib, 2014; Zebal \& Goodwin, 2012; Flavian \& Lozano, 2006; Caruana, Ramaseshan, \& Ewing, 1998). Even so, the focus has been almost solely on public universities. There has been very limited research on the role of market orientation in private universities. There are atleast six major structural and market differences between public and private universities. First, public universities are largely government funded while the incomes for private universities are sourced from endowments and student related fees. There is rarely a contribution from government. Second, in some countries there are considerable differences in structure and processes (Zebal \& Goodwin, 2012). Third, here is evidence that many students apply for admission to private universities because they have been unable to gain admission at a public university (Cabrito, 2004). Fourth, for private universities ultimate survival is dependent on successful student enrolments and the subsequent retention of those students (Ferreira \& Hill, 2007). Fifth, there is tension in the public university values and objectives as compared to those of a private university (Zebal \& Goodwin, 2012). Sixth, Zebal and Goodwin (2012) also argued that each has a distinct niche in the market even though there is some overlap. Given these differences, it is now timely that the role of market orientation in private universities be assessed. It is the intention of this paper to contribute to this discussion.

On the one hand, market orientation has been identified as a significant variable impacting performance. On the other hand, the results of other studies on how market orientation influences performance are not so conclusive, suggesting that market orientation does not directly influence firm performance but rather impacts performance via other mediating variables (Sin, Tse, Yau, Chow, \& Lee, 2005; Singh, 2009). Furthermore, some studies found positive and significant relationships (Julian, 2010) while other studies reported insignificant relationships when performance was measured via alternative measures of performance, for example, market share (Baker \& Sinkula, 2005). Even other studies found that market orientation was related to performance only for certain subjective measures (Rose \& Shoham, 2002), and other studies suggested that market orientation had a negative impact on performance (Cadogan \& Cui, 2004). As such, the evidence of a significant relationship between market orientation and performance is still far from conclusive.

Additionally, it is interesting to note that most previous research on market orientation has been conducted with respect to performance of companies, with limited research being conducted on the relationship between market orientation and university performance (Zebal \& Goodwin, 2012). Grinstein (2008) also suggested that further conceptual and empirical research needs to be conducted on market orientation in different environmental and organiza- 
tional contexts. Only in recent years have researchers explored market orientation in a university (Flavian \& Lozano, 2006; Zebal \& Goodwin, 2012). However, the empirical evidence of a significant relationship between market orientation and university performance still remains inconclusive at best.

Most research on the relationship between market orientation and university performance has been conducted in a developed country context; and given the paucity of studies on this relationship in a developing-country context; the need for such a study was seen. As such, the objective of the study was to examine the relationship between market orientation and private university in Indonesia, a developing country of the Asia-Pacific Region. Therefore, the study's contribution is both contextual and theoretical. The study's findings provides empirical evidence on the relationship between market orientation and private university performance in a developing-country context, overcoming the void in the literature on the relationship between market orientation and performance in private university setting, as previous research had been primarily focused on public university in developed countries.

Scholars have provided many different definetions of market orientation. For instance, Narver and Slater (1990) defined market orientationas an organizational culture that has a set of sharedvalues and beliefs in putting customers first in business planning. Narver and Slater (1990) also suggested that market oriented firms should focus not only on customers but also on competitors and inter-functional coordination. Deshpande and Farley (2004) defined market orientationas a set of cross-functional processes and activities directed at creating and satisfying customers through continuous needs assessment. However, their definition did not emphasize or reflect the importance of competitor orientation. Kohli and Jaworski (1990) defined market orientation as the organization-wide generation of market intelligence pertaining to current and future customer needs, dissemination of the intelligence across departments, and organizationwide responsiveness to it. In their definition, Kohli and Jaworski (1990) emphasized the behavioral aspects and not the cultural aspects of market orientation.

Although many studies have attempted to measure market orientation differently when examining its empirical relationship with different measures of performance most previous research has either adopted the measures developed by Narver and Slater (1990) (e.g., Grinstein, 2008; Hooley, Fahy, Greenley, Beracs, Fonfara, \& Snoj 2003; Sin et al., 2005; Singh, 2009) or that of Kohli \& Jaworski (1990) (e.g., Baker
\& Sinkula, 2005; Kyriakopoulos \& Moorman, 2004; Racela, Chaikittisilpa, \& Thoumrungroje, 2007).

Kohli and Jaworski (1990) were, arguably, the pioneers of market orientation research. Kohli and Jaworski viewed market orientation as the implementation of the marketing concept. In other words, a firm that is market oriented is one that acts consistently with the marketing concept that is, determining the needs and wants of target markets and delivering the desired satisfaction more effectively and efficiently than competitors (Kotler, Adam, Brown, \& Armstrong, 2008). Kohli and Jaworski conducted an extensive review of the marketing literature over the previous 35 years, they conducted interviews with 62 managers both marketing and non marketing managers in the United States, and defined market orientation as "the organization-wide generation of market intelligence pertaining to current and future customer needs, dissemination of the intelligence across departments, and organization-wide responsiveness to it" (Kohli \& Jaworski, 1990).

As such, according to Kohli and Jaworski (1990), there are three important components of market orientation, namely, intelligence generation, intelligence dissemination, and responsiveness. Intelligence generation refers to the collection and assessment of both customer's current and future needs, plus the impact of government regulations, competetors, technology, and other environmental forces. Market intelligence is not the exclusive responsibility of the marketing department. Instead, it is all departments' responsibility. Market intelligence must be communicated and disseminated throughout an organization in both formal and informal ways. The effective dissemination of market intelligence is seen as a vital action since it provides a shared basis for collaborative efforts among different departments (Racela et al., 2007). This is similar to inter-functional coordination in organizations (Grinstein, 2008). Responsiveness refers to the ability of an organization to react to intelligence generation and dissemination. Responsiveness is divided into two activities, namely, response design such as using market intelligence to develop plans and response implementation such as executing the plans.

Narver and Slater (1990) also reviewed the strategy and marketing literatures and suggested that market orientation is a form of organizational culture defining market orientation as "the organizational culture that most effectively and efficiently creates the necessary behaviors for the creation of superior value for buyers and, thus, continuous superior performance for the business" (Narver \& Slater, 1990). As such, market orientation as an organizational culture con- 
sists of three components, namely, customer orientation, competitor orientation, and inter-functional coordination.

With respect to customer orientation, the heart of market orientation is its customer focus. The customer orientation element requires an understanding of customers' needs and wants in order to develop superior products and/or services than their competitors to satisfy customers' needs and wants. It means that for companies to be customer oriented, they need to find out what customer needs and wants are both currently and in the future, in order to create a superior valueadded benefit (Singh, 2009).

As far as competitor orientation is concerned, firms should understand and identify the short-term strengths and weaknesses and long-term capabilities and strategies of both current and future competitors. Employees of every department in market-driven firms share informationabout competitors, and this information can be used to achieve a sustainable competitive advantage for the firm (Grinstein, 2008; Frambach, Prabhu, \& Verhallen, 2003; Singh, 2009). Thus, competitor orientation is viewed as equally important as customer orientation.

In relation to inter-functional coordination, this is where each department is recognized as being important, regardless of whether or not it has anything to do with the marketing function, and each department has a role to play in customer satisfaction (Grinstein, 2008; Im \& Workman, 2004; Singh, 2009). This idea is paralleled with the suggestion that market orientation is not marketing orientation. In other words, a market orientation does not view the marketing department as having the most important role.

Customer orientation and competitor orientation include all of the activities involved in generating market intelligence about customers and competitors and disseminating it throughout the organization (Frambach et al., 2003; Singh, 2009). Moreover, in order to be market oriented, it is important for all departments within the organization to communicate information gathered from customers and competitors and then use their combined efforts to create superior products/services for their customers, thereby satisfying the needs and wants of their customers better than competitors.

The concept of market orientation proposed by both Kohli and Jaworski (1990) and Narver and Slater (1990) are similar in many ways. First, both of the two research teams view market orientation as a continuous rather than a dichotomous variable. Second, both concepts are similar in that they focus on obtaining and disseminating information from customers and competitors in order to achieve a sustainable competitive advantage for the firm. However, Kohli and Jaworski's concept places greater emphasis on customers as opposed to competitors. Third, both concepts emphasize the importance of the combined efforts of all departments in responding to customer needs. Finally, both concepts view market orientation as a three-dimensional construct.

Nevertheless, important differences also exist between the two concepts. For instance, Narver and Slater (1990) explained market orientation as an organizational culture, which led to values and behaviors toward customers and competitors with specific aims (i.e., profitability). However, Kohli and Jaworski (1990) described market orientation as the implementation of the marketing concept and did not identify the cultural aspect of market orientation (Racela et al., 2007).

This study adopts Narver and Slater's (1990) notion of market orientation for at least three primary reasons. First, Narver and Slater's (1990) notion of market orientation separates customer orientation and competitor orientation into two different constructs. As such, it enables the impact of customer orientation and competitor orientation on university performance to be examined separately, thereby enabling identification of which construct has the greatest impact on performance. Second, some researchers have suggested that Narver and Slater's (1990) market orientation construct has better criterion validity and reliability than the Kohli and Jaworski (1990) market orientation construct (e.g., Oczkowski \& Farrell,1998). Finally, other researchers have criticized the poor conceptualization of the Kohli and Jaworski market orientationconstruct in that it does not sufficiently capturethe notion of providing customer value (Pelham, 1997).

\section{Market Orientation and Performance Relationship}

As indicated earlier, most previous studies on market orientation have been conducted on the firm's operations with limited empirical research being conducted on the impact of market orientation in a university context, whether in relation to public university or private university. Only in the past few years have researcher explored issues relating to market orientation in a university context (e.g., Algarni \& Thalib, 2014; Zebal \& Goodwin, 2012; Hemsley \& Oplatka, 2010).

For example, Zebal and Goodwin (2012) investigated 314 faculty members from 15 private universities in Bangladesh and from both business and nonbusiness schools. By employing combination of Narver and Slater's (1990) and Jaworski and Kohli's (1993) market orientation construct namely customer 
orientation, information gathering, and inter-functional coordination,they examined the private university performance (e.g., student growth, market share, teaching and service quality, and overall performance) consequences of a market orientation (customer orientation, information gathering, and inter-functional coordination). Their study found that all four measures for university performance were found to be statistically significant and positively related to the market orientation of the private universities in Bangladesh. Specifically, the impact of market orientation on student growth and market share was stronger.

Hemsley and Oplatka (2010) also studied market orientation in universities. They examined 68 academics in England and Israel that conducted during the academic year of 2007 by employing Narver and Slater's (1990) measures (customer/ student orientation, competitor orientation, and interfunctional orientation). The results of theirstudy suggest that academics in both countries (England and Israel) indicated that their higher education institution is oriented towards meeting students' needs and desires, and cares for students' well-being, teaching and learning. In addition, their respondents alluded to their contribution to internal marketing, i.e., to the promotion of their university through their own work tasks and performances.

Finally, Algarni and Thalib (2014) conducted a conceptual study on the relationship between market orientation, innovation and higher education performance in Saudi Arabia. Their study hypothesized direct positive influence of market orientation on higher education institutions' perceived performance. Moreover, the study developed hypothesis that innovation mediated the relationship between market orientation and performance.

\section{Research Method}

This study was based on an empirical investigation of private university in Kopertis X (Provinces of West Sumatera, Riau, Jambi, and Kepulauan Riau). In order to obtain valid and reliable measures of the variables, previously validated scales were used to measure all variables (Narver \& Slater, 1990). All items were measured via 5-point bipolar scales with scale poles ranging from strongly disagree (1) to strongly agree (5).

The questionnaire was developed and pretested using a small sample of lecturers, with the final instrument in English and a Bahasa Indonesia equivalent with a covering letter and instructions that was mailed to a random sample that included 237 questionnaires and yielding 114 usable questionnaires' being returned, accounting for an effective response rate of $68.1 \%$ and considered to be acceptable.

The questionnaire and covering letter were translated into Bahasa Indonesia and then back-translated into English. The use of only two languages reduced the potential for errors resulting from multiple translations of the questionnaire. Minimizing the diversity of languages also helped ensure construct equivalence and data comparability (Johnson, Cullen, Sakano, \& Bronson, 2001).

To reach the most knowledgeable key informants, the questionnaire was directed to the dean and head of the study program of the private university. From the results of the pretest, it was expected that the dean and head of the study program would be the person most knowledgeable about market orientation and the private university performance.

The instrument contained items identified by the literature intended to measure market orientation and export marketing performance (Narver \& Slater, 1990; Singh, 2009; Zebal \& Goodwin, 2012). The measure of market orientation was adapted from Narver and Slater (1990). In their conceptualization, Narver and Slater identified market orientation as a three-dimensional construct consisting of, namely, customer orientation, competitor orientation, and inter-functional coordination. This study's measure of market orientation comprised 15 items, with six items measuring student orientation, five items measuring competitor orientation, and four items measuring inter-functional coordination.

\section{Customer (Student) Orientation}

Statements were included in the questionnaire to measure customer (student) orientation. All items were adapted from Narver and Slater (1990). These included the extent to which the university was driven by customer (student) needs and satisfaction, the extent to which the university frequently assesses their commitment in serving student's needs, the extent to which competitive advantage is based on the understanding of student' needs, the extent to which strategies are driven by increasing student value, the extent to which the university measures student's satisfaction systematically, and the extent to which the university provides close attention to after-graduation service.

\section{Competitor Orientation}

Statements were included in the questionnaire to measure competitor orientation. All items were adap- 
ted from Narver and Slater (1990). These included the extent to which the university responds rapidly to competitor's actions that threaten them, the extent to which management regularly shares information about competitor's strategies, the extent to which management regularly discusses competitor's strengths and weaknesses with all faculties of university, and the extent to which the university targets students to achieve a competitive advantage.

\section{Inter-Functional Coordination}

Statements were included in the questionnaire to measureinter-functional coordination. All items were adapted from Narver and Slater (1990). These included the extent to which student information is communicated between all the university's faculties, the extent to which internal university functions are integrated to serve student needs, the extent to which the university's faculties understand how employees and lecturers create student value, and the extentto which resources are shared among the university's faculties.

\section{Private University Performance}

Private university performance was measured by four measures of performance namely overall performance, quality of teaching and services, student growth; and market share. Of these measures, the first two were adapted from Bhuian (1992) while student growthwas adapted from previous studies (Douglas \& Craig, 1983; Sefnedi \& Sallam, 2016). The market share measure was that used in Collins (1990).

\section{Results and Discussion}

Prior to analyzing the primary data, the issue of non-response bias is discussed. An "extrapolation procedure" technique was used to assess non-response bias. This assumes that the groupings of actual respondents by an identified criterion are similar to the "theoretical" non-respondents (Armstrong \& Overton, 1977). Frequencies and independent $t$-tests were used to determine whether significant differences existed between the sample of 114 samples and the target population of 237, based on their university classification. No significant differences were identified between the sample and the target population for this classification variable. Therefore, as the results suggest that there were no significant differences between respondents and non-respondents, the sample can be considered sufficient to draw conclusions about private university for the issues under study.
Next, some descriptive statistics of the sample is provided. A profile of the private university participating in the study is presented in Table 1.

Table 1

The Profile of Participating Respondents $(n=114)$

\begin{tabular}{llcc}
\hline Demographic & \multicolumn{1}{c}{ Categories } & Frequency & $\mathbf{( \% )}$ \\
\hline Gender & Male & 62 & 54.4 \\
& Female & 52 & 45.6 \\
Age & 31-40 years old & 19 & 16.7 \\
& 41-50 years old & 77 & 67.5 \\
\multirow{5}{*}{ Education } & More than 50 years old & 18 & 15.8 \\
& Undergraduate & 1 & 0.9 \\
& Master & 94 & 82.5 \\
& Doctor / Ph. D. & 14 & 12.3 \\
Job Position & Dean & 19 & 16.7 \\
& Head of Higher & 2 & 1.8 \\
& Education & & \\
& Chairman of the study & 93 & 81.6 \\
& program & & \\
\hline
\end{tabular}

The data were initially analyzed using confirmatory factor analysis to assess the psychometric properties ofthe instrument. Our primary concern was interpretability of the factors. The dimensions of market orientation, namely, customer (student) orientation, competitor orientation, and inter-functional coordination, all loaded appropriately and no crossloadings above 0.2 were identified, with only factor loadings of above 0.5 being accepted (Table 2). The final reliabilities for all scales were greater than 0.70 . The preliminary results indicated that the psychometric properties of the scales were acceptable, and as such it was appropriate to examine the relationship between market orientation and private university.

The analysis resulted in an $R^{2}=0.512$ suggesting that the three different dimensions of market orientation, namely, student orientation, competitor orientation, and inter-functional coordination explained $51.2 \%$ of the variation in the private university performance. The results also show that all three dimensions of market orientation - student orientation, competitor orientation, and inter-functional coordination (which is approaching significance)-have a significant influence on the private university performance.

The relationship between market orientation and university performance can best be described as the ability of market-oriented university to understand and satisfy students' needs and wants in order to create a sustainable competitive advantage. In other words, universities that know what their students' needs and wants are, both currently and in the future, are able to develop long-term strategies that maximize the university's strengths and minimize its weak- 
Table 2

Summary of Confirmatory Factor Analysis

\begin{tabular}{|c|c|c|c|}
\hline $\begin{array}{l}\text { Factor/Statement } \\
\text { Name }\end{array}$ & $\begin{array}{l}\text { Cronbach's } \\
\text { Alpha }\end{array}$ & Statement & Factor Loadings \\
\hline \multirow[t]{6}{*}{ Student Orientation } & \multirow[t]{6}{*}{0.93} & Our objectives are driven by satisfaction of our students. & 0.89 \\
\hline & & $\begin{array}{l}\text { We measure satisfaction of our student systematically and } \\
\text { frequently. }\end{array}$ & 0.85 \\
\hline & & $\begin{array}{l}\text { Our marketing strategies (such as recruiting and retention) are } \\
\text { driven by our understanding of the possibilities for creating value } \\
\text { for our students. }\end{array}$ & 0.82 \\
\hline & & $\begin{array}{l}\text { We constantly monitor our level of commitment and orientation to } \\
\text { students. }\end{array}$ & 0.86 \\
\hline & & We give close attention to service of students after enrollment. & 0.84 \\
\hline & & $\begin{array}{l}\text { Our strategy for competitive advantage is based on our } \\
\text { understanding of our students' needs. }\end{array}$ & 0.87 \\
\hline \multirow[t]{5}{*}{$\begin{array}{l}\text { Competitor } \\
\text { Orientation }\end{array}$} & \multirow[t]{5}{*}{0.89} & $\begin{array}{l}\text { Those responsible for recruiting students regularly share } \\
\text { information with our department concerning our competitors' } \\
\text { strategies. }\end{array}$ & 0.90 \\
\hline & & We respond rapidly to competitive actions that threaten us. & 0.93 \\
\hline & & $\begin{array}{l}\text { University administration regularly discusses competitors' strengths } \\
\text { and strategies. }\end{array}$ & 0.85 \\
\hline & & $\begin{array}{l}\text { We encourage other staff and faculty outside of our department to } \\
\text { meet with our prospective students and their parents. }\end{array}$ & 0.87 \\
\hline & & $\begin{array}{l}\text { We target potential students where we have or can develop } \\
\text { competitive advantage. }\end{array}$ & 0.91 \\
\hline \multirow[t]{4}{*}{$\begin{array}{l}\text { Inter-Functional } \\
\text { Coordination }\end{array}$} & \multirow[t]{4}{*}{0.91} & $\begin{array}{l}\text { All levels of administration understand how the entire university } \\
\text { can contribute to creating value for students. }\end{array}$ & 0.93 \\
\hline & & Our department is responsive to serving students. & 0.94 \\
\hline & & $\begin{array}{l}\text { Information on recruiting successes and failures are communicated } \\
\text { to members of the department. }\end{array}$ & 0.88 \\
\hline & & $\begin{array}{l}\text { We share information and coordinate resource use with other } \\
\text { departments in the university. }\end{array}$ & 0.89 \\
\hline
\end{tabular}

nesses, enabling the university to take advantage of existing opportunities and minimize potential and current competitor threats, thereby creating superior value for students and stakeholders alike. Such a strategic process is the means by which universities can achieve a sustainable competitive advantage.

A multiple regression analysis was then conducted to examine the relationship between private university performance as a dependent variable and the three different dimensions of market orientation.

Market orientation has been theorized to have a significant and positive effect on performance (Hussain, Syah, \& Akhtar, 2016; Hidayat, Suryana, Afif, \& Cahyandito, 2016; Long, Kara, \& Spillan, 2016; Rodriguez \& Morant, 2016; Zainul, Astuti, \& Arifin, 2016; Njeru \& Kibera, 2014). On the other hand, the results of other studies on how market orientation influences performance are not so conclusive, suggesting that market orientation does not directly influence firm performance but rather impacts performance via other mediating variables (Sin et al. 2005; Singh, 2009). Furthermore, some studies reported insignificant relationships when performance was measured via alternative measures of performance, for example, market share (Baker \& Sinkula, 2005). Even other studies found that market orientation was related to performance only for certain subjective measures (Rose \& Shoham, 2002), and other studies suggested that market orientation had a negative impact on performance (Gholami \& Birjandi, 2016; Cadogan \& Cui, 2004).

Table 3

Multiple Regression Analysis

\begin{tabular}{lcccc}
\hline Variable & Alpha & $\begin{array}{c}\text { Coeffi- } \\
\text { cient }\end{array}$ & $\begin{array}{c}\boldsymbol{T} \text { - } \\
\text { Statistic }\end{array}$ & Sig $\boldsymbol{T}$ \\
\hline Student orientation & 0.93 & 0,658 & 9.049 & $0.000^{* *}$ \\
Competitor orientation & 0.89 & 0,427 & 5.059 & $0.000^{* *}$ \\
Inter-Functional & 0.91 & 0,208 & 3.083 & $0.003 *$ \\
Coordination & & & & \\
\hline$R^{2}=0.512 ; n=114 ; * p<0.05 ; * * p<0.01$ & &
\end{tabular}

The results of this study confirm that a long-term competitive advantage and superior performance can be achieved by being equipped to respond to current and future market needs (Grinstein, 2008; Singh, 
2009). This finding suggests that market orientation is a necessary ingredient for successful private university performance. The impact of market orientation on private university performance in the Kopertis (The Coodinator of Private Universities) X Provinces of West Sumatera, Riau, Jambi, and Kepulauan Riau) is consistent with previous research (Mokoena \& Dhurup, 2017; Algarni \& Thalib, 2014; Zebal \& Goodwin, 2012; Sugoto, 2011; Webster, Hammond, \& Rothwell, 2010; Hemsley \& Oplatka, 2010; Flavian \& Lozano, 2006; Caruana et al., 1998).

The findings of this study suggest that market orientation is a three-dimensional construct consisting of student orientation, competitor orientation, and inter-functional coordination. Each of the three dimensions of market orientation influences private university performance significantly and positively. Student orientation as a predictor variable is the strongest predictor of private university performance. This is followed by competitor orientation, and interfunctional coordination. It is important for the management of private university performance to be aware of these findings for university success. Therefore, for higher export private university performance, the management of private university performance needs to have a dedicated focus on student orientation. In other words, the higher the universities' student orientation, the higher their university performance. The logic behind this contention is that student-oriented university will have greater knowledge of their students' needs and wants, and this knowledge will enable management to better position the university with respect to its competitors, thereby yielding better performance.

With respect to competitor orientation, the results of this study suggest that competitor orientation significantly and positively influences private university performance. This finding further suggests that the higher the private university's competitor orientation is, the higher its performance will be. This is completely understandable because competitororiented universities are aware of the strengths and weaknesses of their competitors as well as their longterm capabilities and strategies. Therefore, by understanding future and current competitors' strengths and weaknesses, the university is able to undertake relevant actions to better position its services, thereby creating superior value for its students more so than its competitors. This finding is also consistent with previous research (Zebal \& Goodwin, 2012; Hemsley \& Oplatka, 2010).

Finally, inter-functional coordination also significantly and positively impacts private university performance. This finding suggests that the higher the private universities' interdepartmental and inter-functional coordination is, the higher their performance will be. Private universities collect information about their student (customers) and competitors and disseminate this information to different departments and for different functions in response to students or customers' needs and wants. The efficiency with which such a process is conducted makes a significant contribution to the private university performance.

\section{Conclusions and Implications}

The present study has extended the literature on university performance and market orientation in several areas. First, the results of this study suggest that the construct of market orientation is three-dimensional, namely, student orientation, competitor orientation, and inter-functional coordination, with all three dimensions being significant predictors of private university performance. This finding supports much of the previous strategic marketing and strategic management literature (Grinstein, 2008; Singh, 2009) and is not surprising given that market-oriented private universities create superior value for students, enabling the universities to achieve a sustainable competitive advantage, which in turn produces superior performance. Second, the constructs developed here can serve as a foundation for further research into university marketing. Third, the study has contributed to a more comprehensive understanding of the success factors in private universities; with empirical evidence being furnished that market orientation is a key success factor in private university marketing and should be included in multivariate models of private university performance. Finally, the study provides empirical evidence of the impact of market orientation on private university performance in a developingcountry context, of which there was a substantial void in the literature. As a result, the study's findings provide empirical support for the notion that issues affecting private university success in a developedcountry context are also applicable to the developing countries of Southeast Asia. Such a finding will enable comparison of findings from a developed country versus a developing-country perspective.

Prior to discussing the directions for future research, some of the study's limitations are noted. One of the limitations of this study is its crosssectional design. The results from this investigation should be considered in this light. Taking this study as a point of departure, longitudinal research is encouraged to examine the effect of market orientation on private university performance over time. As such, future research should continue to monitor and 
evaluate the impact of market orientation in university marketing. Future research should also replicate this study in another Kopertis to see if the findings of this study can be validated using another Kopertis as a sampling frame.

From a methodological perspective, a potential concern might be that all measures are self-reported. While regression modeling is a robust technique, future research could utilize multiple means by which to measure the variables in order to reduce common method variance. Efforts were made in this study to minimize the problem by pre-testing the instrument and selecting measures that minimize item overlap. While utmost care was taken in the development and administration of the instrument, respondents still might not interpret all questionnaire items uniformly. Also, executives who were not fluent in English may have been responsible for some self-selection of returns, which could have been a source of some sample bias. The sample size was also smaller than desirable. Future research should replicate the study with a larger sample. Finally, a replication of this study should examine whether the relationships between the variables still would hold true on a university category basis such as public university, higher education, institute, and academy.

The findings of this study should identify for management of private university generally but, especially in the Indonesian and developing-country context the importance of market orientation, as a driver of university performance. The study findings indicate that better private university performance can be achieved through the implementation of a market orientation. As a result, management of private university will be encouraged to allocate substantial resources in the development and implementation of a market orientation for their university. In the development and implementation of a market orientation for the management of private university, there are three factors that require careful consideration. First, management of private university need to gather continuous information about their students' needs and wants, both currently and in the future. In order to be able to understand what their students' needs and wants are, private universities should be driven by their students' needs and wants and the satisfaction of those needs and wants; the management of private universities should frequently assess their commitment to serving those needs and wants; management should also derive a competitive advantage that is based on the understanding of their students' needs and wants; and the focus for all university management should be on increasing student value. Furthermore, private university management should measure students' satisfaction systematically and pay close attention to after-graduation service. These ingredients of student orientation highlight the significance of the human factor in marketing and the importance of the relationship between students and university management for successful private university performance.

Second, management of private universities must be able to understand and identify the short-term strengths and weaknesses and long-term capabilities and strategies of both current and future competitors. In order to develop these inherent abilities, management of private universities should respond rapidly to competitors' actions that threaten them; they should regularly share information about competitors' strategies; they should regularly discuss competitors' strengths and weaknesses with all university units; and they should specifically target students in order to achieve a sustainable competitive advantage.

Finally, management of private universities must disseminate and respond to the collected information about students' needs and wants together with information on competitors' strengths and weaknesses, both currently and in the future, in a unified manner in order to create superior value for their students. To achieve this, management of private universities should encourage free and open communication about their students throughout all of the university's units; have internal functions that are integrated, with their overall objective being to better serve student needs; understand how employees and lecturers create student value; and share resources among the university's different units.

\section{References}

Algarni \& Thalib, A. M. M. (2014). A framewok of measuring the impact of market orientation on the outcome of higher education institutions mediated by innovation. International Review of Management and Business Research, 3(2), 117125.

Armstrong, J. S. \& Overton, T. S. (1977). Estimating non-response bias in mail surveys. Journal of Marketing Research, 14, 396-402.

Baker, W. E. \& Sinkula, J. M. (2005). Market orientation and the new product paradox. Journal of Product Innovation Management, 22, 483-502.

Bhuian, S. N. (1992). Market orientation and successful not-for-profit marketing: Direct relationships and the influence of professionalism, entrepreneurship, competition and demand. Unpublished Doctoral dissertation, Texas Tech University, Lubbock, TX. 
Cabrito, B. G. (2004). Higher education: An education for the elites? The Portuguese case. Higher Education in Europe, 29(1), 33-45.

Cadogan, J. W. \& Cui, C. C. (2004). Chinese export agents' adoption of export market-oriented behaviors: Measurement and performance relationship. Journal of Asia Pacific Marketing, 3(2), 21-37.

Caruana, A., Ramaseshan, B., \& Ewing, M. T. (1998). Do universities that are more market orientated perform? International Journal of Public Sector Management, 11(1), 55-70.

Collins, J. (1990). A market performance comparison of US firms active in domestic, developed and developing countries. Journal of International Business Studies, 21(2), 271-288.

Deshpande, R. \& Farley, J. U. (2004). Organizational culture, market orientation, innovativeness, and firm performance: An international research Odyssey. International Journal of Research in Marketing, 21(1), 3-22.

Douglas, S. \& Craig, C. (1983). Examining performance of US multinationals in foreign markets. Journal of International Business Studies, 14(3), 51-62.

Ferreira, A. I. \& Hill, M. M. (2007). Organizational cultures in public and private Portuguese universities: A case study. Higher Education, 55, $637-$ 650.

Flavian, C. \& Lozano, J. (2006). Organizational antecedents of market orientation in the public university system. International Journal of Public Sector Management, 19(5), 447-467.

Frambach, R., Prabhu, J., \& Verhallen, T. (2003). The influence of business strategy on new product activity: The role of market orientation. International Journal of Research in Marketing, 20, 377-397.

Gholami, S. \& Birjandi, M. (2016). The effect of market orientation and entrepreneurial orientation on the performance of SMEs. Journal of Current Research Science, 5(1), 361-369.

Grinstein, A. (2008). The effect of market orientation and its components on innovation consequences: A meta-analysis. Journal of the Academy of Marketing Science, 36(2), 166-173.

Hemsley, B. J. V. \& Oplatka, I. (2010). Market orientation in universities: A comparative study of two national higher education systems, International Journal of Educational Management, 24(3), 204-220.

Hidayat, C., Suryana, Y., Afif, F., \& Cahyandito, M. F. (2016). The relationship of entrepreneurial and market orientation, marketing mix, and business performance. International Journal of Economics, Commerce and Management, IV(9), 611-622.

Hooley, G., Fahy, J., Greenley, G., Beracs, J., Fonfara, K., \& Snoj, B. (2003). Market orientation in the service sector of the transition economies of Central Europe. European Journal of Marketing, 37(1), 86-106.

Hussain, H., Syah, F. A., \& Akhtar, C. S. (2016). Market orientation and organizational performance in small and medium sized enterprises. City University Research Journal, 6(1), 166180.

Im, S. \& Workman, J. (2004). Market orientation, creativity, and new product performance in hightechnology firms. Journal of Marketing, 68, 114-132.

Jaworski, B. J. \& Kohli, A. K. (1993). Market-orientation: Antecedents and consequences. Journal of Marketing, 57(3), 53-70.

Johnson, J. L., Cullen, J. B., Sakano, T., \& Bronson, J. W. (2001). Drivers and outcomes of parent company intervention in IJV management: A crosscultural comparison. Journal of Business Research, 52, 35-49.

Julian, C. C. (2010). The market orientation-marketing performance relationship: The empirical link in international joint ventures. International Journal of Trade and Global Markets, 3, 414431.

Kohli, A. K. \& Jaworski, B. J. (1990). Market orientation: The construct, research propositions and managerial implications. Journal of Marketing, 54, 1-18.

Kotler, P., Adam, S., Brown, L., \& Armstrong, G. (2008). Principles of marketing ( $4^{\text {th }} E d$.). Sydney, Australia: Prentice Hall.

Kyriakopoulos, K. \& Moorman, C. (2004). Tradeoffs in marketing exploitation and exploration strategies: The overlooked role of market orientation. International Journal of Research in Marketing, 21(3), 219-240.

Long, Z., Kara, A., \& Spillan, J. E. (2016). Market orientation and firm performance: An empirical analysis of Chinese IT enterprises. Sixth AsiaPacific Conference on Global Business, Economics, Finance and Social Sciences (AP16Thai Conference) ISBN: 978-1-943579-10-5 Bangkok-Thailand. 18-20 February, 2016.

Mokoena, B. A. \& Dhurup, M. R. (2017). Effects of market orientation and barriers to market orientation on university performance: A study of universities of technology in South Africa. International Business \& Economics Research Journal, 16(1), 17-30. 
Narver, J. C. \& Slater, S. F. (1990). The effect of a market orientation on business profitability. Journal of Marketing, 54(4), 20-35.

Njeru, W. G. \& Kibera, F. N. (2014). The perceived effects of the three components of market orientation on the performance of tour firms in Kenya. European Scientific Journal, 10(25), 266-285.

Oczkowski, E. \& Farrell, M. A. (1998). Discriminating between measurement scales using nonparametric tests and two stage least squares estimators: The case of market orientation. International Jo urnal of Research in Marketing, 15(4), 349-366.

Pelham, A. M. (1997). Mediating influences on the relationship between market orientation and profitability in small industrial firms. Journal of Marketing Theory and Practice, 5(3), 55-76.

Racela, O., Chaikittisilpa, C., \& Thoumrungroje, A. (2007). Market orientation, international business relationships and perceived export performance. International Marketing Review, 24(2), 144-163.

Rodriguez, A. L. L. \& Morant, G. A. (2016). Linking market orientation, innovation and performance: An empirical study on small industrial enterprises in Spain. Journal of Small Business Strategy, 26(1), 37-50.

Rose, G. M. \& Shoham, A. (2002). Export performance and market orientation: Establishing an empirical link. Journal of Business Research, $55,217-225$.
Sefnedi \& Sallam, M. A. (2016). The marketing competency-export performance relationship: Evidence from Indonesia. International Journal of Research Science \& Management, 3(5), 1-9.

Sin, L. Y. M., Tse, A. C. B., Yau, O. H. M., Chow, R. P. M., \& Lee, J. S. Y. (2005). Market orientation, relationship market orientation, and business performance: The moderating effects of economic ideology and industry type. Journal of International Marketing, 13(1), 36-57.

Singh, S. (2009). How market orientation and outsourcing create capability and impact business performance. Thunderbird International Business Review, 51, 457-471.

Sugoto, A. S. (2011). Orientasi dan strategi pemasaran dalam menciptakan keunggulan posisional serta dampaknya terhadap kinerja perguruan tinggi. Trikonomika, 10(1),19-30.

Webster, R. L., Hammond, K. L., \& Rothwell, J. C. (2010). Customer and market orientation within AACSB member business schools: Comparative views from three levels of administrators. American Journal of Business Education, 3(7), 79-92.

Zainul, M., Astuti, E. S., \& Arifin, Z. (2016). The effect of market orientation toward organizational learning, innovation, competitive advantage, and corporate performance. Journal of Administrative Sciences and Policy Studies, 4(1), 1-19.

Zebal, M. A. \& Goodwin, D. R. (2012). Market orientation and performance in private universities. Marketing Intelegence and Planning, 30(3), 339-357. 